\title{
Jurnal
}

Manajomen Polayanan Publik

Administration Of E-Invoicing Value Added Tax (Comparative Study between Indonesia and Australia)

Supply Chain Integration (SCI) Fashion Products Made By SMEs In Response To Improve Performance Development Of Tourism In West Java

Analysis on Fees Exemption Policy of Land and Building Rights Acquisition in Jakarta

Analysis of Tax Authority Readiness in Tax Policy on Digital Economy

Implementation of Large Scale Social Restrictions Policy (PSBB) in Bogor District Government

Critical Success Factors In Implementing Employee Information System Based On E-Government In The Bureau Of Public Affairs At The Regional Secretariat Of West Java Province

Implementation of Billboard Tax Policy in the City of Bandung

Public-Private Partnership In Water Supply Of DKI Jakarta 


\section{Analysis of Tax Authority Readiness in Tax Policy on Digital Economy}

Bambang Firmansaha, Ning Rahayu ${ }^{b}$

a b Faculty of Administrative Sciences, University of Indonesia

\begin{abstract}
ABSTRAK
Fenomena sosial efek dari berkembangnya teknologi yang dikenal dengan ekonomi digital menghadirkan beragam model bisnis baru yang membuka banyak peluang skema penghindaran pajak. Sehingga OECD merekomendasikan rencana aksi tentang ekonomi digital berupa Action Plan 1, tetapi rekomendasi ini sebelumnya tidak menjadi prioritas bagi otoritas pajak Indonesia. Di sisi lain, otoritas pajak dalam lima tahun terakhir tidak memenuhi target penerimaan, sementara telah diketahui bersama bahwa nilai transaksi atas ekonomi digital ini sangat besar dan belum dipajaki. Sehingga sangat mendesak dan perlu bagi Indonesia untuk segera mengenakan pajak atas ekonomi digital ini. Untuk itu diperlukan peraturan dan kesiapan. Pengenaan pajak atas ekonomi digital tertuang dalam Undang Undang Nomor 2 Tahun 2020. Tujuan penelitian ini adalah menganalisis kesiapan otoritas pajak terkait kebijakan pengenaan pajak atas ekonomi digital. Metode penelitian ini adalah metode kualitatif deskriptif analitis dalam bentuk narasi, tabel dan gambar di mana peneliti mengembangkan abstraksi, teori dan informasi dari informan kunci. Teori yang digunakan adalah teori kesiapan dan perpajakan internasional serta dipadukan dengan rekomendasi OECD. Berdasarkan hasil penelitian menunjukkan bahwa ototitas pajak telah siap tetapi masih memerlukan penyempurnaan peraturan berupa peraturan petunjuk pelaksanaan dan pembenahan sumber daya manusia dalam bentuk program peningkatan dan pemerataan kompetensi pegawai terkait ekonomi digital.
\end{abstract}

Kata Kunci: Ekonomi digital; otoritas pajak; kesiapan; rencana aksi 1; e-commerce

\section{ABSTRACT}

The social phenomenon effects of technology development known as digital economy presents new business models open many opportunities for tax avoidance schemes. So, OECD recommends action plan on digital economy in action plan 1 , but this recommendation has not yet become a priority for Indonesian tax authority. On the other hand, tax authority has not achieve the tax revenue target in the past five years, while it is generally known that digital economy transaction value is very large and has not been taxed. So, it is urgent and necessary for Indonesia to immediately tax digital economy. So, regulations and tax authority readiness are needed. Tax policy on digital economy is contained in Law number 2 of 2020. The study purpose is to analyze tax authority 's readiness to carry out tax policies on digital economy. This research method is a descriptive qualitative analytical method in narratives, tables and pictures in which researcher develops abstractions, theories and information from key informants. The theory used is the readiness, international taxation theory integrated with OECD recommendations. Based on study results showed that tax authority was ready but still needed improvements to the implementing regulations and improvement of human resources competency about digital economy.

Keywords: Digital economy; tax authority; readiness; action plan 1; e-commerce

\section{ARTICLE HISTORY}

Submited : $13 / 06 / 2020$

Accepted : 21/06/2020

Published : 28/08/2020

\section{KATA KUNC}

Ekonomi digital; otoritas pajak kesiapan; rencana aksi 1; e-commerce

\section{KEYWORDS}

Digital economy; tax authority; readiness; action plan 1 e-commerce bambang.firmansah@gmail.com

Faculty of Administrative Sciences, University of Indonesia 


\section{INTRODUCTION}

In the era of the industrial revolution 4.0, competition is not only between the big and the small, but the time for the fast and the slow. Not just business problems, anyone who is responsive to technological advancements can win the competition compared to those who are late in adapting. As with taxes, when an authority is unable to keep abreast of developments and advancements in digital trends, a nation will be disadvantaged by the huge risk of potential loss of state revenue. This is a challenge for regulators, bearing in mind that the current tax regulations, at the time of drafting, have not yet considered and taken into account the impact of digital regulations. Consequently, the old taxation law product will be very easily handled by taxpayers who abuse the existing regulations.

The digital revolution not only affects the patterns and forms of behavior of every human being, but is followed by the presence of many new forms of business today such as e-commerce, payment services, application services, online advertising, cloud computing, high frequency trading, participative networked platforms (OECD, 2014). Furthermore, the disruption occurring now is not only opening up opportunities for an increasingly broad and diverse economic business, but also has the potential to cause a negative impact if there is a lack of management and supervision.

It is important to involve tax reform technology that has been realized by the Directorate General of Taxes (DGT). The development of information technology actually began in the 1990s when a new tax payment system began to be built (Gunadi, 2019). Digital technology that continues to grow at this time generally runs very fast in front of the infrastructure development that has been carried out by DGT, and all developments by DGT are less visible to taxpayers and the public, for example DJP Online, electronic Tax Invoice and electronics Witholding Tax Slip. Tax authorities must be observant in seeing the conditions, business schemes and technological developments of taxpayers as well as carefully in conceptualizing tax regulations in order to answer the developments and challenges of this digital technology era (Gunadi, 2019).

Government Regulation in Lieu of Law Number 1 of 2020 concerning State Financial Policy and Financial System Stability for Handling the Corona Virus Disease 2019 (Covid-19) and / or in the Context of Facing Threats that Endanger the National Economy and / or Financial System Stability take some of the points from the concept of the omnibus law namely permanent establishment (PE), Trading through the Electronic System and the imposition of Value Added Tax (VAT) on Intangible Taxable Goods and Taxable Services from Foreign Tax Subjects related to digital service transactions which then has become Law Number 2 of 2020. The weakness of this regulation still requires technical guidance in its implementation. Although this regulation has followed the recommendations of the OECD BEPS Action Plan 1, which is related to the determination of PE based on economic presence (significant economic presence), but this regulation still requires many refinements based on the recommendations of the OECD BEPS Action Plan 1, for example related to how to determine profit allocation for Indonesia as a basis taxation for Indonesia.

Based on Google's research, Temasek and Bain \& Company in accordance with figure 1 shows how great the potential for e-commerce transactions in Indonesia. Indonesia can indeed be considered as one of the largest digital economy countries in the Southeast Asia region. The research illustrates that in 2020 Indonesia's digital economy is projected to reach 40 billion US dollars and it is predicted that in 2025 it will reach 133 billion US dollars (Kompas, 2019). 
Figure 1. Projection of the value of the digital economy in Southeast Asian countries 2019 and 2025

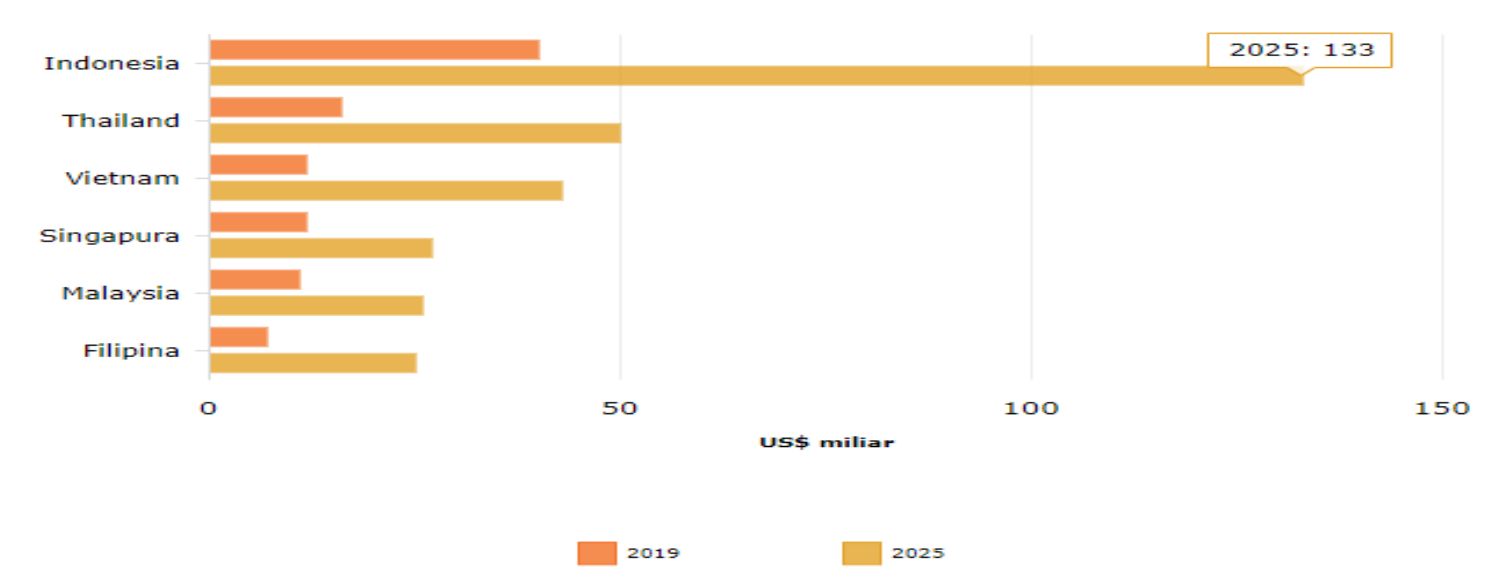

Source : Kompas (2019)

In 2015, the G20 in the OECD has issued fifteen action plans to deal with losses in BEPS in many countries related to the consequences of injustice in the tax sector. The fifteen action plans were specifically formed by the BEPS inclusive framework consisting of 129 countries, of which Indonesia is a member. John Hutagaol, Director of International Taxation, DGT, said that there are four minimum standards that must be implemented, the four minimum standards are action plan 5th, namely harmful tax practice with Government Regulations in Lieu of Laws Number 1 of 2017 concerning access to financial information for taxation interests, then action plan 6th namely misuse of P3B then an action plan 13th namely transfer pricing documentation by issuing the minister of finance regulation number PMK-213/ PMK.03 /2016 and finally action plan 14th namely settlement of international tax disputes. Indonesia has already implemented the four minimum standards, although not all of the minimum standard action plans are productive in generating state revenue. Multinational entities have taken advantage by using a combination of domestic tax regulations with multiple tax avoidance agreements.

The tax planning scheme carried out is like this: a) utilizing loophole as well as differences in tax regulations of countries so that their income is not taxable; b) move income to jurisdictions where there is no or very small-scale business so that as little as possible to pay taxes or not taxable.

The BEPS OECD action plan beyond the minimum standards that has not yet been implemented in Indonesia is the BEPS 1 action plan on the digital economy. It is well known that the taxation of this digital economy is very important and should be a priority, because it has a huge tax potential to boost the achievement of state tax revenue, this should be made a breakthrough by the Indonesian Tax Authority to explore the potential of state revenue. In the past five years, the DGT has not reached the state revenue target according figure 2 below: 
Figure 2. Indonesian Tax Revenue 2015-2019

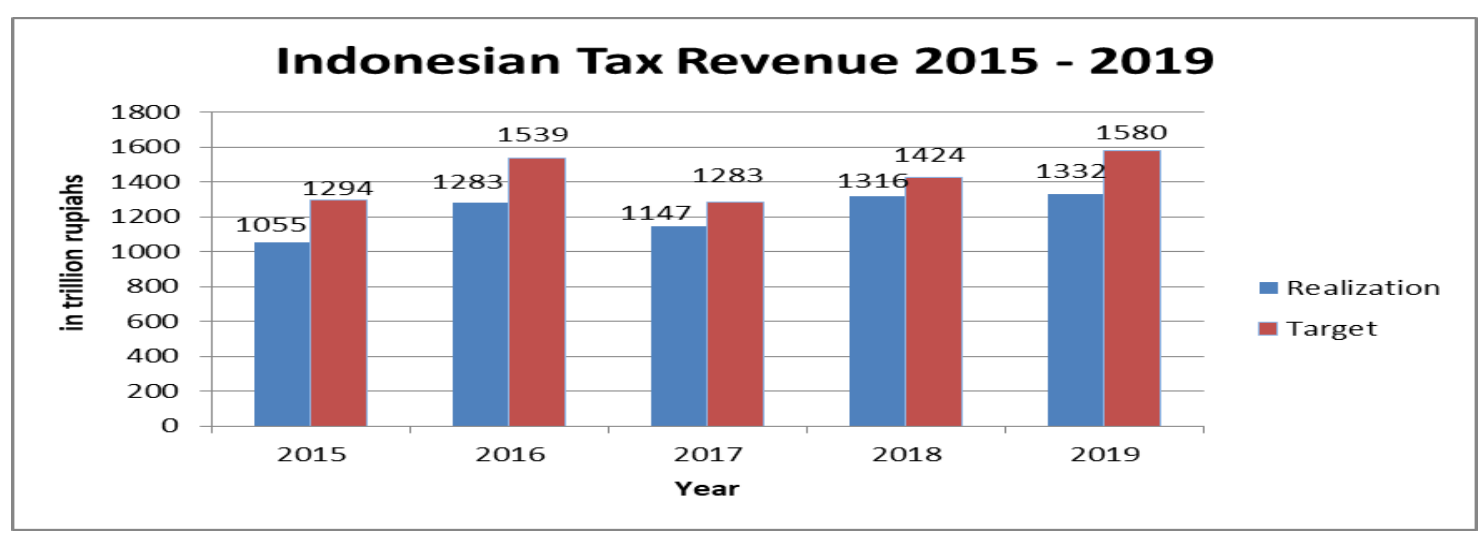

Source : Kementerian Keuangan (2020)

Based on Google's research, Temasek and Bain \& Company according to figure 1, it is predicted that the potential of Indonesia's digital economy in 2025 will be 133 billion dollars, which when converted to an average exchange rate of 1 United States dollar of 14 thousand rupiahs is 1,862 trillion rupiahs, so that clearly the potential for VAT on the digital economy can be calculated to reach 186.2 trillion rupiah, excluding the income tax aspect. This digital economy has not been taxed in Indonesia. This potential tax excavation should be made a breakthrough by DGT to obtain state revenue. For this reason, Indonesia is in dire need of readiness in many ways including regulatory support, human resources, in this case the DGT tax authorities, taxpayers and other stakeholders to carry out OECD BEPS Action Plan 1 recommendations in taxation of the digital economy. And considering the number of multinational companies that avoid tax by utilizing loophole which is the implication of the absence of tax policies on the digital economy in Indonesia. The potential tax in the form of VAT on the digital economy is of enormous value, which is approximately 186.2 trillion rupiahs or has a portion of 11.78 percent of the 2019 tax revenue target last year which amounted to 1,580 trillion rupiahs. Based on the problem, the implications and the large portion of the potential portion of the tax on the digital economy encourages researchers to conduct in-depth research on DGT's readiness in taxation policies on the digital economy in accordance with international tax readiness and theory combined with OECD BEPS Action Plan 1 recommendations.

\section{LITERATURE REVIEW}

According to Tapscott (Tapscott, 1996), digital economy is a social phenomenon that affects economic systems, where the phenomenon has a characteristic as an intelligence space, consisting of information, some access to information instruments, information capacity and information processing. The components of a successful digital economy were initially identified as e-commerce activities, the digital distribution of goods and services and the information technology (ICT) industry. According to Zimmerman (Zimmerman, 2000), the digital economy is a concept that is often used to describe the global impact on the rapid development of information and communication technology that has an impact on socioeconomic conditions. This theory becomes a view of the interaction between the development of innovation and technological progress that have an impact on micro or macro economics. Areas that are affected are the fields of product and service product development (research), production, sales or supply depending on the 
reach of digital technology. According to Bloch (Bloch et al., 2006), in the digital economy, their service companies correspond to certain services that are in accordance with certain specific requests or special offers, offers have been characterized as private and individual or private offers. In order for the digital economy to benefit society and entrepreneurs, an appropriate regulatory framework is needed so that a competitive market climate can be formed and a balance is in developing ideas for making products and innovations.

The social phenomenon of the effects of the rapid development of information and communication technology (ICT) certainly affects changes in business patterns of individuals and organizations. An organization that tries to respond to changes or dynamics of the internal and external environment is often referred to as organizational readiness. On the other hand, this expected level of change is also a pillar of public policy implementation (Purwanto, 2019). So it is important to measure the rate of change. The readiness in this research is related to how an organization responds to changes. In the internal and external environment of the organization changes occur that lead to an organizational response, whether an organization can respond positively and can adapt well to changes that occur in that particular environment, or even it even tends to respond to negative things and persist with conditions in the organization. According to Lubis and Huseini (2009), various forms of changes in the environment that occur today are inevitable for organizations to become adaptable and move dynamically for the existence and sustainability of the organization. Vakola (2013) states that changes in an organization are considered as an integral part of an organization's life.

Readiness in this research is related to how an organization responds to changes. Some experts have defined the organization as follows: 1) organization as a player in a rule of the game (institutional), can be in the form of individuals or groups involved in achieving certain goals. An organization is bound by existing rules, values and norms and can force these individuals/groups (North, 1992); 2) Lubis and Huseini provide organizational understanding from Barnard and Davis, namely: "a social unity of groups of individuals (people) who interact with each other according to structured patterns in a certain way so that each member of the organization has its own duties and functions, and as a unity certain objectives, and also have transparent boundaries, so that organizations can be separated clearly and firmly from their environment "(Lubis and Huseini, 2009). Both definitions above, readiness and organization provide important points relating to organizational readiness, namely, the presence of preventive measures, effective change, involvement of an individual / group, restrictions with certain rules / norms, and the achievement of common goals. To reinforce the understanding of organizational readiness, the following is presented an understanding of organizational readiness from several experts, namely : 1 ) organizational readiness is an existing trust in individuals (employees) stating that the organization can not only make a change by itself without involving employees in a change process which can be called successful (Cinite, 2009); 2) the classic definition conveyed by Weiner et al that organizational readiness is basically an organization's ability to undergo soft or non-radical transformation in responding to the hopes and needs of the internal and external environment (Narayanamurthy, 2018); 3) organizational readiness refers to existing mechanisms, then processes that can encourage or disrupt changes such as organizational structure, culture, climate, leadership commitment, and others. Hierarchical organizational structure and forms of communication that are not flexible, it can inhibit 
a change in the organization (Vakola, 2013).

Researchers limit the understanding of organizational readiness based on the explanation of the concept above is the ability of an organization to respond to changes both in the internal and external environment, involving the role of individuals and groups, which aims to reduce resistance and to achieve the desired organizational changes in accordance with the values/rules in the organization. Then the readiness of the organization appears in the forms, ways, and processes of an organization in responding to a change. There are five elements in the formation of readiness systems in organizations, namely messages, interpersonal and social dynamics, influential strategies, attributes of change agents, and judgments (Armenakis, 1993), namely: 1) messages, the main elements of readiness in change between organizational members are "Message of change". There are 2 (two) messages, namely: a) the need to change (discrepancy), namely the difference between the final goal desired by the present conditions, and b) the ability of individuals and / or groups to change (efficacy). The message discrepancy aspect communicates information about a constant need to change such as competition, changes in government policy; 2 ) interpersonal and social dynamics, change is an effort that requires beliefs from groups of individuals who interact to change beliefs, behaviors, and intentions based on aspects of message discrepancy and efficacy. Change agents must understand the differences of individual and group readiness and what factors influence individual and group interpretations of the message; 3 ) influential communication strategies, to influence individual cognition are appropriate for creating readiness for organizational change: persuasive communication (both oral and written) and active participation. The third strategy is managing external information sources; 4) the agent of change agents, the effectiveness of the change strategy depends on the agent of change with certain attributes, namely the factors of credibility, trust, friendliness, and expertise of change agents; 5) assessment, basically the assessment of the readiness of individuals, teams and organizations, will very much depend on the availability of time, funds, expertise, and the importance of the assessment carried out. Readiness is assessed by methods such as surveys, interviews, questionnaires, or observations and according to the reliability and validity of the data. Transparency in evaluating work results with clear and measurable indicators can also be disseminated to all parties as a way to generate positive competition and productivity (Setiawan, 2018).

The digital revolution will continue to penetrate the conventional market lane by using cross-border transaction opportunities that are increasingly widespread and widespread. Cross-border transactions require an understanding of cross-taxation, also known as international taxation. Please note, according to Rohatgi (2002: 1) and Gunadi (2007: 8), there are four objectives for the preparation of provisions in international taxes for a country, namely: 1 ) obtain a fair share of income from cross-border transactions; 2 ) increasing fairness in taxation; 3 ) strengthen the competitiveness of the domestic economy; 4) ensure a fair balance between capital export neutrality and capital imports. Then based on tax linkages, people generally draw jurisdiction over taxation on three principles (Gunadi, 2007: 55), namely: 1) citizenship; 2) domicile; 3) Source of income. And according to Surahmat (2005: 21) the reasons for the imposition of international double taxation there are three types of conflicts including; 1 ) conflict between the principle of domicile and the principle of source (the concept of authority over territory); 2) conflict due to different definitions of "population"; 3) different notions of "source of income". The characteristics of tax avoidance that are not allowed according to Santoso and Rahayu (2013: 19) are as follows: 1 ) not aiming at a good business; 2) solely in the context of tax avoidance; 3) not in accordance with the spirit and intension of parliament; 4) the existence of transaction engineering in such a way that costs or losses arise. While the imposition of taxes on 
the digital economy is unreasonable apart from the term permanent establishment (PE), the following concepts that make a digital transaction into a PE have been submitted by several experts, including the following; a) the concept of a server as a PE, some taxation experts argue that a server can be categorized as a PE because it is a physical facility used to carry out sales transactions. Vink (1998: 67) asserts that PE arises when companies not only provide machines but also operate and maintain these machines for their own accounts; b) the concept of Virtual PE, the concept of Virtual PE that was initiated by Hinnekens as quoted from Bohorquez $(2016,94)$ states that the physical presence in taxes for e-commerce will be more clearly seen in significant commercial activities on a continuous basis related to non-business activities to the existence of a place of business in the source country.

Previous studies relevant to this study is firstly, a journal written by Clinton Alley and Joanne Emery, Taxation of Cross-border e-Commerce Response of New Zealand and Other OECD Countries to BEPS Action 1, published in the Journal of International Taxation in September In 2017, this journal focuses on OECD BEPS Action Plan 1 recommendations related to the analysis of New Zealand consumers in selecting products with competitive prices, good quality and practical as well as policy analysis on reducing the import duty threshold. Second, the journal written by Annet Wanyana Oguttu, Tax Base Erosion and Profit Shifting in Africa - Part 1: What Should Africa's Response be to The OECD BEPS Action Plan ?, was published in The Comparative and International Law Journal of Southern Africa in November 2015, This journal emphasizes the analysis of BEPS practices and analysis of the importance of OECD BEPS Action Plan recommendations to countries in Africa as well as analyzing responses or responses from countries in Africa to the BEPS Action Plan OECD recommendations. While this research is aimed at providing a comprehensive picture and analyzing the readiness of the Indonesian tax authorities both related to the readiness of regulations and DGT employees according to the readiness theory combined with the OECD BEPS Action Plan 1 recommendations on the digital economy.

\section{RESEARCH METHODS}

This study uses a qualitative approach because this study provides a comprehensive review of the phenomena discussed and uses a qualitative descriptive analysis, a method that is to provide a description of the facts in accordance with the data obtained with the aim of knowing the extent of the development of the Indonesian tax authority (DGT) in the taxation policy on the digital economy and its problems according to international tax readiness and theory combined with OECD BEPS action plan 1. Recommendations this is not in order to prove the truth of the theory (Creswell, 1994). The stages in analyzing this research are collecting data that will be used then analyzing the literature on the data that has been obtained and the results of interviews with informants (Irawan, 2006). Based on the results of the interview then poured in writing and rereading all the data that has been collected and then the researcher takes some data which is the main key of this research. Through the main concepts that are carried out simplification in a scale, then the researcher will draw conclusions from the data that has been obtained. Data collection will be carried out several times until finally a complete, comprehensive and clear understanding of the matter under study is obtained. Data collection was carried out through interviews with informants or informants namely people 
who are competent in understanding the issues discussed in this study. The informant group or resource persons are from the Ministry of Finance which includes the Directorate General of Tax (DGT) and the Fiscal Policy Agency (FPA), Tax Consultants, Taxation Practitioners and Observers, Taxation Academics, Taxpayers, Ministry of Economic Coordinators, Ministry of Taxation Trade, Central Statistics Agency (CSA), Ministry of Communication and Information and Bank Indonesia (BI).

\section{RESULTS AND DISCUSSIONS}

\section{OECD'S Recommendations}

Important points related to the OECD 2018 Interim Report are as follows: first, it elaborates on digitalization, business models, and their relationship to the process of value creation. Second, in the 2018 OECD interim report, a summary was given of the development of the implementation of the BEPS package related to the digital economy. Some of these include: (i) preventing the avoidance of Permanent Establishment (BUT) status (Action 7), (ii) ensuring the application of value creation in transfer pricing (Action 8-10), (iii) strengthening the provisions of the Controlled Foreign Corporation (CFC) (Action 3), to (iv) progress in the Multilateral Instrument (MLI) (Action 15). Third, regarding the imposition of cross-border digital economic business tax, which is classified in 4 (four) groups, namely: 1) efforts to modify the BUT threshold; 2) unilateral action with a mechanism withholding tax; 3 ) countries that impose a final tax (turnover tax); 4) countries that have a special taxation regime targeting large multinational companies. There are 3 (three) things that can be learned from the various 'unilateral' policies, namely: (i) aiming to protect and expand the tax base where the customer or user is located; (ii) uses elements related to the market as a tax base, for example: sales, places of consumption; and (iii) reflecting dissatisfaction with the profit allocation model of the current international tax system. Fourth, members of the inclusive framework have diverse views in responding to the development of the digital economy, particularly regarding the need to change the international tax system and the extent to which these changes need to be made. This report states that there are still differences of opinion. There are groups of countries that speak out about the discrepancy between the jurisdiction where profits are taxed and the jurisdictions where values (profits) are formed. Fifth, there is no agreement among members of the inclusive framework regarding the benefits or the need for initial measures before the Final Report 2020. A number of countries actually oppose the initial measures because they can be at risk for the prospect of consensus building. However, for countries that are pro-temporary, there are several elements of policy that must be considered: 1) must be in accordance with international agreements; 2) must be temporary and must be changed based on global consensus, if it already exists; 3 ) must target precisely (targeted) and does not apply generally; 4) not giving excessive tax burden; 5) as much as possible does not affect the start-up business, the establishment of new businesses, and small businesses; 6) does not add compliance costs and provide complexity. Sixth, explore further the impact of digitalization on the tax system. For example, the presence of an online platform (apartment rental sites, online taxis, etc.) can actually encourage the growth of gig and sharing economies, which in turn will facilitate economic growth and increase income. Therefore, the government needs to ensure that there is an equal tax treatment and ensure there is no specific tax regime for the business model. In addition, the challenges of the digital economy can also be overcome through taxpayer education that aims to improve compliance and the collaboration between the authorities and online platforms in collecting transaction value data. From the administrative side, the existence of the digital economy can also create the effectiveness of compliance services, reduce compliance costs, and improve services to taxpayers. 
Seventh, the proposal for a "Unified Approach" and "Globe", an inclusive framework issued a policy note on handling the challenges of tax digitizing the economy. Under this policy note, the inclusive framework agrees without prejudice, to do work on the following two pillars: 1) pillar one, discusses the allocation of taxation rights between jurisdictions and explains proposals for new profit allocation and nexus rules based on the concept of "significant economic presence" and exploitation of "user participation" and "intangible marketing" in jurisdictions; 2) Pillar Two (proposal of "GloBE") calls for the development of a coordinated set of rules to address the ongoing risk of structures that allow MNEs to transfer profits to jurisdictions where they are not subject to tax or very low taxes. The inclusive framework approved the work program at their meeting in Paris on May 28-29 2019 based on the two pillars identified in the policy note.

The following is a summary of the meeting proposals: 1 ) it is important to design solutions that draw the support of all members of the inclusive framework, the secretariat proposal for a "unified approach" has been developed with this goal in mind; 2 ) the proposal is summarized at a relatively general level. This refers to three alternatives under Pillar One and the subsequent public consultation process, and the aim is to identify the main features of a solution, which will include the following: a) scope, this approach covers a highly digital business model but is broadly focused in businesses that face direct consumers with further work that must be done according to the threshold and carve-out. Extractive industries are assumed to be out of reach. b) new nexus, for business scope, creates new relationships, not dependent on physical presence but is largely based on sales. The new Nexus with a threshold includes a country-specific sales threshold that is calibrated to ensure that jurisdictions with smaller economies can also benefit. It will be designed as a provision for a new independent agreement. c) New profit allocation rules going beyond the arm's length principle, it creates new profit allocation rules that apply to taxpayers within the scope, and regardless of whether they have a marketing or distribution presence in the country (a permanent establishment or a separate subsidiary) or sell through an unrelated distributor.

At the same time, this approach largely maintains current transfer pricing rules based on the arm's length principle but complements them with solution-based formulas in areas where tensions in the current system are highest; $d$ ) increased tax certainty delivered through the three tiers mechanism.

This approach increases tax certainty for taxpayers and tax administration and consists of three tier profit allocation mechanisms, as follows: 1 ) ammount $A$, the portion of residual income deemed allocated to the jurisdictional market using the formula approach, namely new taxation rights; 2) ammount $B$, fixed remuneration for basic marketing and distribution functions that occur in market jurisdictions; and 3) ammount $\mathrm{C}$, the binding and effective dispute prevention and resolution mechanism relating to all elements of the proposal, including any additional benefits in which domestic functions exceed basic activities are compensated with ammount B. Pillar two elements, under the pillar two work program, inclusive framework members agree to exploration without a basis of prejudice, problems and design choices in connection with the development of a coordinated set of rules as illustrated in the diagram below : 
Figure 3. Global Anti Base Erosion (GloBE)

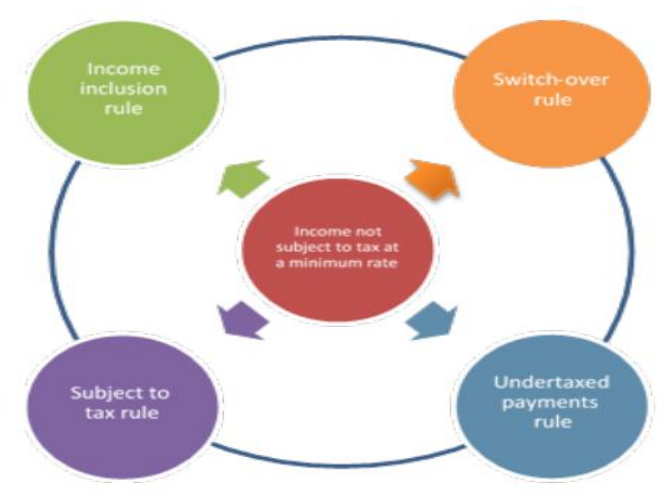

Source : OECD (2014)

According figure 3, the four components of the GloBE proposal are: 1) an income inclusion rule, which will burden foreign branch or entity-controlled revenues if the income is taxed at an effective level below the minimum rate; 2 ) an under tax payment rule, which will operate by refusing to withhold or impose sourcebased tax (including withholding tax) for payments to related parties if that payment is not taxed at or above the minimum rate; 3 ) a switch-over rule, which will be entered into a tax agreement that will allow the residence of a jurisdiction to switch from an exception to a credit method where profits are due to permanent establishment (PE) or come from immovable property (which is not part of $\mathrm{PE}$ ) is subject to an effective tariff below the minimum rate; and 4) a subject to tax rule, which will complement the unfavorable payment rules by subjecting payments to deductions or other taxes at the source and adjusting eligibility for benefit agreements at certain income items where payments are not taxed at the minimum level. Some technical aspects and the design of the GloBE proposal depend on the policy choices to be taken agreed in the context of the inclusive framework. There are three aspects of the technical design of the GloBE proposal: 1) the use of financial accounts as a starting point for determining the tax base, and also different mechanisms for overcoming time differences; 2 ) the level of blending is based on the GloBE proposal, i.e. the extent to which MNE can combine high and low taxes from various sources by considering efficient income tax in determining effective (mixed) tax rates on such income; and 3) experience and views, carve-out and threshold are considered as part of the GloBE proposal.

\section{Tax Authority Readiness}

Tax authorities include institutions and employees of the Directorate General of Tax (DJP) within the Directorate of International Taxation, Large Taxpayers Regional Office (LTRO), Special Jakarta Regional Office (SJRO) and Fiscal Policy Agency (FPA) related to taxation international, the first element of readiness is a message, the main element of readiness in change between members of an organization is the "message of change". There are two messages, namely: a) the need to change (discrepancy); and b) the ability of individuals and/ or groups to change (efficacy). The Digital Economy Task Force has been formed at the DGT and Indonesia has implemented the OECD recommendations through the fiscal policy body, the Minister of Finance has signed the Multilateral Instrument (MLI). There has been support and direction from the leadership, with the issuance of Government Regulations in Lieu of Laws Number 1 of 2020 which later 
became Law Number 2 of 2020. It is necessary to immediately determine the right taxation instrument, in terms of the appropriate taxation scheme related to this digital economy. Meeting the OECD BEPS Action Plan 1 recommendation, in the third point interim report, regarding the imposition of cross-border digital economic business tax. Related to the instrument, from a comparative perspective such as in India in 2016, namely equalization levy, the need to pursue state revenue and expand this digital tax base, unlike the scheme used by the UK in 2015 through Diverted Profit Tax (DPT) or Google Tax, which is not too successful, with a settlement system. If the scheme used by India and France is easily carried out for overseas payments for certain digital services, then there will be a direct turn over tax or additional tax. This scheme is considered the most effective and efficient for Indonesia.

Then regarding the aspect of Value Added Tax (VAT), based on the 2018 OECD interim report recommendation, fifth point, regarding the benefits or the need for initial measures before the Final Report 2020. Allowed for countries that are pro to the existence of temporary measures, there are several elements of policy with consideration: 1) according to international agreements; 2) are temporary; 3) targeting precisely (targeted); 4) not giving excessive tax burden; 5) has no impact on start-up businesses, the establishment of new businesses, and small businesses; 6) does not add compliance costs and is not complicated. Indonesia undertook this unilateral measures by issuing Regulation Number 2020 which was later changed to Law Number 2 of $\mathbf{2 0 2 0}$ which was later reduced to Minister of Finance Regulation Number PMK-48 / PMK.03 / 2020 concerning Procedures for Appointing Collections, Collecting and Depositing, as well as Reporting Value Added Tax on Utilization of Intangible Taxable Goods and / or Taxable Services from Outside the Customs Area in the Customs Area through Trade through the Electronic System. Indonesia followed the considerations recommended by the OECD to readily issue a unilateral regulation, seeing the portion of the cake for the digital economy continuing to expand and expand. So, before it will become even more difficult and complex to tax, the Indonesian government will take the right step to issue Law Number 2 of 2020, while waiting for recommendations related to the unified approach and global consensus to be agreed and recommended globally by the OECD.

Based on the Armenakis journal (Armenakis et.al., 1993), discrepancy is the belief that the necessary changes require organizational mechanisms that are different from the desired end goal which emphasizes the importance of changes in external contextual factors in justifying the needs in organizational change. While aspects of efficacy affect the mindset, actions, and emotions of individuals and / or groups that are used to overcome differences of opinion related to change. The researcher analyzes that both of these are related to awareness factors of differences that can produce positive energy in building a spirit of change in this case tax regulation on the digital economy and the factor of confidence as efficacy can be seen as a perceived ability to overcome differences, differences here are related before they exist regulations and after the existence of regulations and conditions both institutionally and staff (HR). All employees and institutions of the tax authority are very confident and aware of the importance and urgency of the taxation on the digital economy. This awareness and belief must be disseminated to external parties both to taxpayers, tax consultants, taxation academics, business associations, ministries and related institutions in order to create the same end goal as determined namely state revenue is achieved. Law Number 2 of 2020, one of which is the imposition of taxes on the digital economy, is ammunition and guidance for tax authorities, in this case 
DGT in taxing an increasingly complex and ever-expanding digital economy.

The second element of readiness, the element of interpersonal and social dynamics. With the issuance of regulations that can be easily understood by all parties, including taxpayers, DGT staff, and other relevant stakeholders, followed by dissemination and dissemination on target, it is hoped that this regulation on digital economic taxation in Indonesia can later be implemented by all relevant parties. The stages that have been carried out include the first, Indonesia has received assistance from the OECD, IBFD, ITO, trainning and Focus Group Discussion (FGD) on the digital economy. DGT and FPA have always been involved in several OECD working parties related to the digital economy. Readiness related to the digital economy is considered quite good, meaning that DGT awareness from the institutional side is already quite high. Indeed, the challenges faced by the tax authorities differ, not all related to this. But it requires some kind of obligation to learn certain things with independent training. With material that has been recorded and known to the entire Fiscus, so anytime and anywhere, the Fiscus can access training material such as this digital economy. As digital economy taxation is already urgent because of the development of the new world, everyone must know it. It is expected that with training materials and frequently asked questions (FAQ) that have been recorded in video format and can be accessed online by all the tax authorities and the wider community can learn them and are considered important so that all parties know what is the DGT's concern at this time. In the near future DGT will need to develop employee competencies, such as programmed and continuous seminars and training on international taxation especially digital economy, interpretation of tax treaty and transfer pricing. It is indeed necessary to immediately formulate a program to standardize the competency of the fiscal authorities related to these matters. It is expected that the DGT will immediately create a road map for the DGT employee competencies, how DGT has a strategy to continuously improve the competency of the tax authorities. So, the tax authorities have good analytical skills and standards regarding international taxation.

The third element of readiness, the communication strategy, which includes active participation, persuasive communication and external information management can be taken several important points including the need to know that the meetings held by the OECD and the task force, the DGT is always involved and express opinions. Even DGT also got 1 (one) representative from the OECD namely Mr. Andrew Aurbach, who can help to communicate DGT with the OECD and Inclusive Framework. On the other hand, DGT has coordinated within the Ministry of Finance with FPA and external Ministry of Finance with the Ministry of Communication and Information, Ministry of Trade, Central Statistics Agency, Bank Indonesia and other external stakeholders. DGT needs to immediately prepare an information technology (IT) system related to digital economic taxation, DGT needs to immediately have data to validate company data over the top, even though this is self-assessment, but when DGT wants to test the data, DGT automatically has to have data first first The existing difficulties, first, e-commerce itself is fairly new, secondly, there has not been a collection of digital economic data because according to information from CSA, because the need for digital economic data for Ministries and Institutions varies according to their respective interests.

Regarding external information management, DGT coordinates with other institutions. The Coordinating Ministry for the Economy considers that the supervision of the digital economy must continue to be pursued in order to create a fair playing field. There is information that DGT should know, including domestic and foreign business actors having the same and commensurate obligations in accordance with transactions 
carried out in Government Regulation Number 80 Year 2019, especially for business actors, trade organizers through electronic systems that have large capitalization in Indonesian market. For e-commerce in the Minister of Trade Regulation Number 50 Year 2020, the definition of goods, related to the package of goods (physical) in the Ministry of Trade must coordinate with the Directorate General of Customs and Excise, but if digital goods, the Ministry of Trade must coordinate with the Ministry of Communication and Information. One of the characteristics of digital goods is that they can be downloaded, can be streamed, and have a threshold. If digital goods meet the threshold, it is considered to be present in Indonesia. For the purposes of taxation, the regulation used is Law No. 2 of 2020. For consumer protection, because in trade is not only the taxation aspect, and there is also consumer protection contained in Government Regulation Number 80 of 2019, in which one article writes that business actors must have a person in charge, a contact person, a vehicle for trading, traded products that are subject to the supervisors of their respective sector institutions in this case the relevant ministries. For example, if selling drugs must obey the rules of the drug and food control agency. So that this Regulation of the Minister of Trade also regulates licensing for the marketplace that in addition to the drug seller has a business license for electronic system organizers and must also fulfill the requirements mandated in the sector's institutional development guideline in this case the Ministry of Health, so that the e-commerce perpetrators are blamed when a case occurs. As there have been cases of buyers buying drugs in e-commerce, it was found out that the drug was illegal, finally related platforms were later subjected to penalties, actually there are platforms that are user generated content (UGC), which do not know if a business actor sells what items. So, in this case arrangements have been made in the context of supervising e-commerce licensing according to the respective institution's supervisory institutions.

The DGT's coordination with the Ministry of Communication and Information is related to understanding foreign companies that are popular with the term over the top. In the Ministry of Communication and Information is not known clearly and in terms of regulations related to over the top terminology, what is in the Ministry of Communication and Information is an application that is shaded by an electronic system. So both in Law Number 19 of 2016 regarding information and electronic transactions and its revisions and Government Regulation Number 71 of 2019 there is no over the top term, but what exists is the implementation of an electronic system. Law Number 19 of 2016 regarding information and electronic transactions, regulates the electronic system, about who is organizing it, so that there is a registration procedure for the organizer of the electronic system. The Ministry of Communication and Information receives registration of both public and private services. In this case there is coordination between ministries and institutions again, for example fintech can obtain a business license if it has registered with the Ministry of Communication and Information. So, if you have not registered the website with the Ministry of Communication and Informatics, the Financial Services Authority will not issue the fintech operating license. Some sectors already require suppliers / users to register at the Ministry of Communication and Information. For over the top companies like Google, Yahoo should be the same as an electronic system organizer. So in this case before registering his business to the relevant supervisory agency must register with the Ministry of Communication and Information. Researchers assess this system and procedure is very good to continue to prioritize the system of coordination and crosscheck with each other ministries and institutions so that public data available is always transparent and valid. 
The most important coordination and especially must continue to be built and developed by the DGT is coordination with central statistical agency related to the system, this e-commerce data recording system will later be built and developed by this agency. The problem is that there is no institution that has an ecommerce business directory, who is doing this business, and this is only related to formal business, not to mention informal ones such as employees who while trading, how can it be known, such as employees then try while trading in the marketplace and then not reported, no data. The Indonesian e-Commerce Association (IDEA) also does not have this data. CSA conducted a data search, found 79 companies. Previously the Minister of Communication and Information Technology had gathered 20 of Indonesia's biggest marketplace CEOs, but still did not provide data. Then related to the collection of data to the marketplace and business actors, initially a Government Regulation needs to be made so that their responses are better than those made by law. Then the Government Regulation has two implementing regulations, the first is the minister of trade regulation number 50 of 2020, the second in CSA is the regulation of the head. Related to e-commerce data collection, what if e-commerce does not provide data, who will provide sanctions. This is stated in ministry of trade regulation number 50 of 2020 in article 14 regarding data collection obligations, and in article 54 regarding sanctions. Although the sanctions are still weak, it will be coordinated with the ministry of communication and information, it may be recommended to block those who do not comply with their reporting obligations. The policy that was designed, related to the collection of this data is being conceptualized at CSA. Now discussions continue. There are problems experienced by CSA, firstly related to coordination with CSA 's IT systems, secondly related to the authority of data collection in which CSA is the recipient of its mandate. In terms of infrastructure and human resources, CSA is ready to carry out this task. CSA has also been warned by the Digital Economy Team that if they formulate regulation of the CSA's head, they are expected to involve it. The concept that is carried out first separates the types of formal and informal, formal ones such as those using marketplaces and websites, while the informal ones are those who trade using social media using the enumeration approach, throughout Indonesia will be done with sample techniques. It is hoped that this informal business will soon be captured. For formal businesses asked to report on a monthly basis, for informal businesses asked to report annually.

In Regulation of the Minister of Trade Number 50 of 2020, a clause states that the marketplace must provide a link to One Single Submission (OSS), each trader must register, the registration requirements are more difficult, but specifically for traders to facilitate registration. If all data has been entered in the system, in the future there will be no need to survey again. Which by this system made two models, first for the marketplace requested daily transactions, which are reported monthly. Second, non-marketplaces are asked for monthly transaction data only. Non-marketplaces are like traveloka, whatever traits are traded, but in collaboration with other parties. For the marketplace requested daily transaction data along with its commodities, this will be asked to the Digital Economy Team and business actors. There are two types of data requested by business actors, first, annual company profile and second, daily transaction data that is reported monthly. BI said that the data requested from the players later was expected to be as complete as possible, it was hoped that it would be no less than the collection of data in the previous $\mathrm{BI}$, it should be noted that BI collected data on the four largest Indonesian marketplaces. In the future raw data from the marketplace and business players will be directly accessible to DGT and BI. DGT requires data on marketplaces and business actors to add data on population registration numbers, telephone numbers and Taxpayer Identification Numbers whose data can only be accessed by DGT. CSA is also not allowed to access the data. Business actors will be coded with Identification Data (ID) only, may not include name, identity details are unknown. With this condition, CSA 
does not violate the 1997 Law on data confidentiality. Because it does not provide individual data. If BI approaches the transaction ID, for example shop 01, where the store is located, what shipping costs, it is possible for buyers to transact with several stores. Also being designed for non-marketplaces, such as vertical classified: jobstreet, horizontal classified like Olx, Kaskus. This classification was carried out by IDEA. Tokopedia, Lazada, Bukalapak, Shopee who already have a non disclosure agreement (NDA) with BI. DGT has entered into agreements with 13 marketplace companies. It is targeted that this regulation of the head global draft will be completed in June 2020, then in July 2020 it will be finalized. The concept of data transfer of business actors to CSA is detailed as follows: it is recommended for the marketplace to use File Transfer Protocol (FTP), while non-marketplaces use online input.

The fourth element of readiness, the agent of change, regarding the factors of credibility, trust, friendliness, and expertise, DGT and FPA strive to achieve these four things both domestically and internationally. DGT and FPA always strive to improve the ability of employees. Meanwhile, the readiness of the DGT is not only about digital economy taxation. The issue of credibility, trust, friendliness and expertise, is about the big picture of institutions, discussing the BEPS Action Plan 1 is more inclined to the digital giant. If only employees in special units who understand and master the digital economy are considered to be no problem, but in the future it is expected to look at the wider DGT employee coverage. Trust (trust), regarding the balance of rights with obligations, then hospitality, friendly attitude and responsiveness must be put forward, to complaints or questions Taxpayers. Regarding the expertise of change agents, it is demanded that the will and ability to learn continuously, learning teams need to be formed at each level of leadership in the context of synergy and innovation methods of socialization according to the times. As for expertise, DGT does not yet have the most suitable program for personal development improvement, among Regional Offices it is often conducted training of trainers, is expected to quickly develop and need to be worked out comprehensively, so as to produce optimal output.

DGT is the most authoritative and credible institution in order to socialize tax imposition on digital economy, compared to other institutions, such as business associations or tax consultants. Therefore, the formulated policy must be socialized so that it can be implemented by business actors as taxpayers. Related to trust, trust will arise if the rights of taxpayers are also considered balanced with their obligations. An imbalance between rights and obligations will lead to anti-trust conditions, for example by doing tax avoidance or even tax evasion by taxpayers. Regarding friendliness, the level of friendliness between people is most likely not the same, given the nature of friendliness is a natural trait, like there are people who are low profile or high profile. However, friendly attitude in terms of tax services must be prioritized and responsive (quick response) to taxpayer complaints or questions. A protocol must be made that is the standard of service for Fiscus individually and in groups. Like a shop assistant who tries to be friendly and swift to serve buyers, the tax authorities are demanded to be friendly and alert and quick to respond in serving taxpayers. Regarding the expertise of change agents, there is a demand for will and endless learning ability, from the elite level to the implementers. The goals and benefits of learning as an ongoing process are attitudes responsive to existing problems and anticipatory to the possibility of problems that arise in the future. Learning teams need to be formed at each level of leadership in order to synergize and innovate socialization methods in accordance with the times. In terms of DGT's hospitality, it is much better. DGT does not yet have the most 
suitable program to carry out personal development improvement. So that agents of change, who want to dihire, at what level, who will pursue them, this needs to be clarified, at least the tax office in tax offices related to foreign people and entities must at least all have mastered this digital economy, such as the tax office in Jakarta Regional Office Specifically for the LTO Regional Office. Alumni of Special Regional Offices and Regional Offices of LTO will already be good trainers for others. In this way it is hoped that it will quickly develop, and planned and comprehensive employee training programs are immediately made sustainable.

The final element of readiness, fifth, readiness assessment, related to the aspects of expertise, funding, time and assessment. Organizational preparation in accordance with Law No. 2 of 2020, has been carried out by the DGT to immediately form a Digital Economy Task Force. Cooperation between directorates within the DGT and between the Directorate Generals and FPA within the Ministry of Finance has also been quite effective and quite good, the readiness of each individual tax authorities, DGT team and organization to be able to formulate taxation on the digital economy has also been done well. Now international taxation has been managed by a separate Directorate, the International Taxation Directorate. In terms of expertise, it is important to note that DGT has sent many employees to study international tax and digital economy. Then in terms of funding, this is a challenge, it needs good IT (information technology) capabilities, it needs a lot of investment, this IT was developed not only for digital economy, but for all administrative purposes this DGT has led to digitalization. So that taxpayers do not need to report physically anymore. Related to this element of readiness assessment in terms of resources, DGT is able, staying political will or commitment from the leadership, because this is very important. It needs a long term to deal with this digital economic phenomenon, and a model or roadmap for employee competency development needs to be made. Determination of the content that will be delivered related to the digital economy and then who will do it and who will be the target, then the training model through the training of trainer (TOT) mechanism, the target of which is employees in the LTRO and SJRO environment and then proceed with doing TOT, maybe can be applied. About the budget, the provision of training, it is necessary to bring in experts from abroad and within the country which involves many sectors and parties who understand the economy and IT. It is recommended that in anticipation of the development of the digital economy, DGT resources (such as time, funds and expertise) should be directed to web-based services and not just desktop-based services. Proven with regard to VAT or VAT, the web-based e-Tax Invoice service has been proven to be able to significantly increase VAT receipts as well.

\section{CONCLUSIONS}

The tax authorities are ready to implement a tax policy on digital economics based on readiness theory and follow the OECD BEPS Action Plan 1. Marked with DGT has formed a Digital Economy Task Force involving many directorates within the DGT environment. Then a few months ago the Minister of Finance also signed a Multilateral Instrument (MLI) related to changes in defining BUT in international relations between countries. Great support also came from the country's leadership by issuing a unilateral regulation namely Government Regulations in Lieu of Laws Number 1 of 2020 which later became Law No. 2 of 2020 concerning the imposition of taxes on the digital economy. 
DGT and FPA have received assistance and training from international institutions such as the OECD, IBFD, Worldbank and other related institutions. DGT and FPA have always been involved in several OECD working parties related to the digital economy, in addition to that DGT also received 1 (one) representative from the OECD named Mr. Andrew Aurbach who can help to communicate DGT with the OECD and Inclusive Framework. Digital Economic Task Force the DGT immediately prepares data and information technology (IT) systems related to digital economic data and information from domestic and foreign companies. Regarding the factors of credibility, trust, friendliness and expertise, DGT and FPA strive to achieve these four things both domestically and internationally. DGT and FPA always strive to improve the ability of employees. The ministries and institutions also collaborated to form a Digital Economy Team initiated by the Coordinating Ministry for the Economy and consisting of the Ministry of Trade, CSA, the Ministry of Communication and Information, Bank Indonesia and the Ministry of Finance (DGT and FPA) in order to equalize perceptions and coordinate tax policies related to this digital economy. It is expected that with all these preparations, the Tax Authorities, Taxpayers and all related parties will be able to carry out tax policies on the digital economy properly, all taxpayers can receive their rights and carry out their tax obligations fairly and well, this digital economy can be taxed properly and can provide a large and significant role for national tax revenues and welfare for all Indonesian people and support a good and comfortable atmosphere and climate for investment both from within and outside the country.

It is recommended to the tax authorities related to all duties and authority in general and this digital economic tax policy specifically that is necessary to immediately determine the tax instrument in terms of the right and best tax policy scheme for all parties. The tax policy scheme is technically later outlined in the form of the Director General of Taxes. It is hoped that these technical regulations will be easily understood by all parties, both DGT employees, taxpayers, and other stakeholders, which are immediately followed by dissemination and socialization.

\section{ACKNOWLEDGEMENTS}

Researchers would like to thank the informants from the Ministry of Finance (Ministry of Finance) which includes the Directorate General of Tax (DGT) and the Fiscal Policy Agency (FPA), Consultants, Practitioners and Observer of Taxation, Academics, Taxpayers, Ministry of Economic Coordinator (Ministry of Economic Affairs), The Ministry of Trade (Ministry of Trade), Central Statistics Agency (CSA), Ministry of Communication and Information and Bank of Indonesia (BI) have provided information, insights and thoughts related to this digital economy.

\section{REFERENCES}

Alley, C and Emery, J. (2017) Taxation of Cross-Border E-Commerce Respon of New Zealand And Other OECD Countries To BEPS Action 1. Journal Of International Taxation, Volume 28, Issue 7

Armenakis, A. A.; Harris, S. G.; Mossholder, K. W. (1993). Creating Readiness for Organizational Change. Human Relations, 46 (6), 681-703. DOI: 10.1177/001872679304600601.

Bloch, M., Pigneur, Y dan Sergev, A. (2006). On the road of electronic-Commerce- A Business Value 
Framework, gaining competitive advantage and some research issues. Working paper University of Laussane, Laussane SwissBohorquez, A.C.V. (2016). Virtual Permanent Establishment : An Approach to the Taxation of Electronic Commerce Transactions. Revista de Derecho Fiscal, enero-junio de 2016, p94

Cinite, I.; Duxbury, L. E. and Higgins, C. (2009). Measurement of Perceived Organizational Readiness for Change in the Public Sector. British Journal of Management, 20, 265-277. DOI: 10.1111/j.14678551.2008.00582.x

Creswell, John W. (1994). Research Design Qualitative and Quantitative Approach. London, Sage Publication. Gunadi. (2007). International tax. Jakarta, Institute of Publishing, Faculty of Economics, University of Indonesia

Gunadi et.al. (2019). Pajak 4.0. Challenges and Dynamics of Taxation Amid The Digital Revolution from the Point of View of Academics And Practitioners. Kontan Publishing. Jakarta

Irawan, Prasetyo. (2006). Qualitative \& Quantitative Research for Social Sciences. Jakarta, Department of Administrative Sciences, Faculty of Social and Political Sciences, University of Indonesia

Kementerian Keuangan Republik Indonesia. (2020). (https://www.Kemenkeu.go.id, 10 March 2020, accessed on 15 March 2020)

Kompas Cyber Media. (2019). (https://www.Kompas.com, 7 October 2019, accessed on 25 February 2020)

Lokuge, S.; Sedera, D.; Grover, V.; and Xu, D. (2018). Organizational Readiness for Digital Innovation: Development and Empirical Calibration of a Construct. Information \& Management, https://doi.org/10.1016/j.im.2018.09.001.

Lubis, H. S.B dan Huseini, M. (2009). Pengantar Teori Organisasi: Suatu Pendekatan Makro. Depok: Departemen Ilmu Administrasi,Fakulitas IImu Sosial dan Politik ,Universtas Indonesia.

Mrayyan, M. T.; Modallal, R.; Awamreh, K.; Atoum, M.; Abdullah, M.; and Suliman, S. (2008). Readiness of Organizations for Change, Motivation and Conflict-handling 246 Intentions: Senior Nursing Students' Perceptions. Nurse Education in Practice, 8, 120-128

Narayanamurthy, G.; Gurumurthy, A.; Subramanian, N.; and Moser, R. (2018). Assessing the Readiness to Implement Lean in Healthcare Institutions. A Case Study. International Journal of Production Economics, 197,123-142.

North, D. C. (1990). Institution, Institutional Change and Economic Performance. Cambridge-UK: Cambridge University Press

OECD. (2014). (https://www.oecd.org/ctp/tax-challenges-digital-economy-discussion-draft-march-2014.pdf, 14 April 2014, accessed 30 March 2020)

Oguttu, A.W. (2015). Tax base erosion and profit shifting in Africa - part 1: what should Africa's response be to the OECD BEPS Action Plan? The Comparative and International Law Journal of Southern Africa, Vol. 48 , No. 3, pp. 516-553

Purwanto, T., Suwaryo, U., \& Mulyawan, R. (2019). Desentralisasi Pendidikan (Studi Efektifitas Alih Kelola Kewenangan Pengelolaan Pendidikan Sekolah Menengah Umum oleh Pemerintah Provinsi Jawa Barat). Jurnal Manajemen Pelayanan Publik, 3(1), 58. https://doi.org/10.24198/jmpp.v3i1.26379

Rohatgi, Roy. (2002). Basic International Taxation Volume 1: Principles. London, BNA International Inc

Santoso, Iman dan Ning Rahayu. (2013). Corporate Tax Management: Review efforts to manage corporate tax conceptually-practically. Jakarta: Ortax

Sekretariat Kabinet Republik Indonesia. (2020). (www. Setkab.go.id, 18 May 2020, accessed on 20 May 2020) Setiawan, E. (2018). Budaya Organisasi Pada Dinas Kesehatan Kabupaten Sumedang. Jurnal Manajemen 
Pelayanan Publik, 2(1), 9. https://doi.org/10.24198/jmpp.v2i1.20099

Surahmat, Rachmanto. (2005). Double Tax Avoidance Agreement, Jakarta, PT Gramedia Pustaka Utama

Tapscott, Don. (1997). The Digital Economy: Promise and Peril in the Age of Networked Intelligence. New York: Mcgraw-Hill. ISBN 0-07-063342-8

Vakola, M. (2013). Multilevel Readiness to Organizational Change: A Conceptual Approach. Journal of Change Management, 13 (1), 96-109.http://dx.doi.org/10.1080/14697017.2013.768436

Vink, Martin. (1998). Fiscal Actualiten Caught in The Web: The Tax and Legal Implications of Electronic Commerce. Washington: Price Waterhouse.

Zimmermann, H. (2000). Understanding the Digital Economy: Challengers for New Business Models. AMCIS 2000 Proceedings. 